\title{
MICROBIAL BIOMASS CARBON AND ENZYMATIC DEGRADATION OF CARBOHYDRATES BY APPLICATION OF VERMICULITE TO RECLAIMED SUBSTRATES
}

\author{
Boyka Z. Malcheva ${ }^{1}$
}

\begin{abstract}
A vegetation experiment was carried out with different amounts of vermiculite mixed with humus depot substrates, tailings pond and mine, in different proportions, and with an application of mineral fertilization and liming. Biomass carbon of microbial origin has the highest values after the addition of $10 \%$ vermiculite, simultaneous application of fertilization and liming, and alone fertilization, compared to controls, without ameliorants. The activity of the studied enzymes - cellulase, amylase, invertase and catalase increased with increasing concentration of vermiculite, as well as in the combined application of fertilization and liming. The values of microbial biomass carbon and enzymes are highest in the variants with substrates from the mine.
\end{abstract}

UDC Classification: 502, DOI: https://doi.org/10.12955/pns.v1.120

Keywords: reclaimed substrates, vermiculite, microbial biomass, enzymes

\section{Introduction}

Soil formation at mining sites is essential for restoring ecosystem functions and depends on soil organic matter accumulation and development of an active microbial community. According to Stefanova et al. (2019) there are soil formation processes in reclaimed terrains whose speed and qualities depend on the soil-forming materials and the type of vegetation. Creating a future sustainable ecosystem by biological re-cultivation of mine embankments and incorporating them into the surrounding landscape is essential (Petrov, 2019). Technical and biological reclamation measures should be identified to limit the occurrence of erosion processes, soil pollution and create conditions for vegetation development (Petrova, 2009). The monitoring of microbiological and enzyme activity is an important part of the methods for assessing the effectiveness of reclamation treatments applied to degraded soil. The microbial community and enzyme activity are important biological indicators of soil quality and net ecosystem productivity in natural and regenerated areas (Dimitriu et al., 2010; Burns et al., 2013). Easily degradable soil organic matter is rapidly consumed by microorganisms and then degradation is dominated by the accumulation of microbial biomass (Ladd et al., 1995; Veen and Kuikman, 1990).

Chodak and Niklińska (2012) established that mining soils contain significantly less organic C and total N. However, in some of them, microbial biomass and basal respiration reach values typical of natural forest soils. Microbiological and enzymatic (dehydrogenase, urease and phosphomonoesterase) activity are positively related to microbial biomass. In a study of enzyme activity and microbial biomass in the upper soil layer after brown coal mining, Baldrian et al. (2008) found that bacterial content, cellobiohydrolase and $\beta$-xylosidase were more affected by increasing the age of the site, while fungal biomass, chitinase and phosphatases were more affected by season. According to Wang et al. (2008) analyzes of microbial quantity (mainly bacteria followed by actinomycetes and micromycetes) and enzyme activity in tails contaminated with iron show positive correlations. The soil microorganisms and enzymatic activities of urease, invertase, cellulase, and acid phosphatase are reduced in tailings with high concentrations of $\mathrm{Pb}, \mathrm{Zn}, \mathrm{Cd}$, and $\mathrm{Cu}$ (Qiang et al., 2018). The accumulation of microbial biomass in the initial soil-forming process in reclaimed sites is mainly due to the active development of non-spore-forming bacteria (Stefanova and Petrov, 2019).

Kuimei et al. (2012) found that the inoculation of mycorrhizal fungi into mini substrates leads to an increase in organic carbon and enzyme activity after 12 months of ryegrass cultivation and improves soil fertility during mine reclamation (Bi et al., 2007; Wang et al., 2009). The addition of coarse wood fragments increases the functional diversity of the microbial community, but not enzymatic activities of highland reclamation areas after oil production in Northern Alberta, Canada (Kwak et al., 2015). The activity of $\beta$-glucosidase enzyme in soil is considered to be a good indicator for efficiency of recultivation processes (Doni et al., 2012; Cele and Maboeta, 2016). The addition of bio-crust significantly improves soil microbial biomass and enzyme activities (alkaline phosphatase, dehydrogenase and urease) in the upper layer of copper-contaminated tailings ponds (Chen et al., 2009). A study of microbial and biochemical properties is necessary to evaluate the recovery and

\footnotetext{
${ }^{1}$ University of Forestry, Sofia, Bulgaria, boika.malcheva@ gmail.com
} 
quality of soil after disturbance (Harris, 2003; Gil-Sotres, 2005). The purpose of the present study is to determine the biomass carbon accumulation and the degree of enzymatic degradation of carbohydrates when applying vermiculite to reclaimed substrates.

\section{Materials and methods}

A vegetation experiment was conducted in March 2019 with different amounts of vermiculite (5\%, $10 \%$ and $20 \%$ ) mixed with substrates in different ratios, with mineral fertilization $\left(\mathrm{N}_{150} \mathrm{P}_{150} \mathrm{~K}_{150} \mathrm{~kg} / \mathrm{ha}\right)$ and liming (substrate neutralization) (table 1). Substrates from the mine are contaminated with heavy metals, mainly copper and cadmium above the maximum permissible concentrations (MPC). Whereas in the soil and tailings substrates, the concentrations of these elements are below the MPC. The arsenic content follows the same distribution - higher concentrations in the mine samples and lower in the other variants.

\begin{tabular}{|c|c|c|c|c|}
\hline Substrate & Variant & $+5 \%$ vermiculite & $+10 \%$ vermiculite & $+20 \%$ vermiculite \\
\hline \multirow{5}{*}{$\begin{array}{l}\text { Embankments } \\
\text { from mine (M) }\end{array}$} & I & $\begin{array}{l}\text { Without liming (L), } \\
\text { without fertilizing (F) }\end{array}$ & $\begin{array}{l}\text { Without liming, } \\
\text { without fertilizing }\end{array}$ & $\begin{array}{l}\text { Without liming, } \\
\text { without fertilizing }\end{array}$ \\
\hline & II & $\begin{array}{l}\text { Without liming, } \\
\text { with fertilizing }\end{array}$ & $\begin{array}{l}\text { Without liming, } \\
\text { with fertilizing }\end{array}$ & $\begin{array}{l}\text { Without liming, with } \\
\text { fertilizing }\end{array}$ \\
\hline & III & $\begin{array}{l}\text { With liming, } \\
\text { without fertilizing }\end{array}$ & $\begin{array}{l}\text { With liming, } \\
\text { without fertilizing }\end{array}$ & $\begin{array}{l}\text { With liming, } \\
\text { without fertilizing }\end{array}$ \\
\hline & IV & $\begin{array}{l}\text { With liming, } \\
\text { with fertilizing }\end{array}$ & $\begin{array}{l}\text { With liming, } \\
\text { with fertilizing }\end{array}$ & $\begin{array}{l}\text { With liming, } \\
\text { with fertilizing }\end{array}$ \\
\hline & 0 & \multicolumn{3}{|c|}{ Without vermiculite and without fertilizing } \\
\hline \multirow{4}{*}{$\begin{array}{l}\text { Soil from humus } \\
\text { depot (SD) }\end{array}$} & $\mathrm{I}$ & Without fertilizing & Without fertilizing & Without fertilizing \\
\hline & II & With fertilizing & With fertilizing & With fertilizing \\
\hline & 0 & \multicolumn{3}{|c|}{ Without vermiculite and without fertilizing } \\
\hline & $0 \mathrm{~F}$ & \multicolumn{3}{|c|}{ Without vermiculite and with fertilizing } \\
\hline \multirow{2}{*}{$\begin{array}{l}\text { Tail from tailing } \\
\text { (T) }\end{array}$} & I & Without fertilizing & Without fertilizing & Without fertilizing \\
\hline & II & With fertilizing & With fertilizing & With fertilizing \\
\hline
\end{tabular}

Studies were conducted on the 30th and 95th days from the start of experimentation - before and after liming and fertilizing, respectively, using the following methods:

- Microbial biomass carbon (MBC) - fumigation spectrophotometric method (Cai et al., 2011);

- Cellulase, amylase and invertase activity - spectrophotometric method (Gradova et al., 2004);

- Catalase activity - manganometric titration method (Khaziev, 1976).

\section{Results and discussion}

Starting materials used for the vegetation experience are poor in total organic carbon. MBC on the 30th day is presented in the following figure 1.

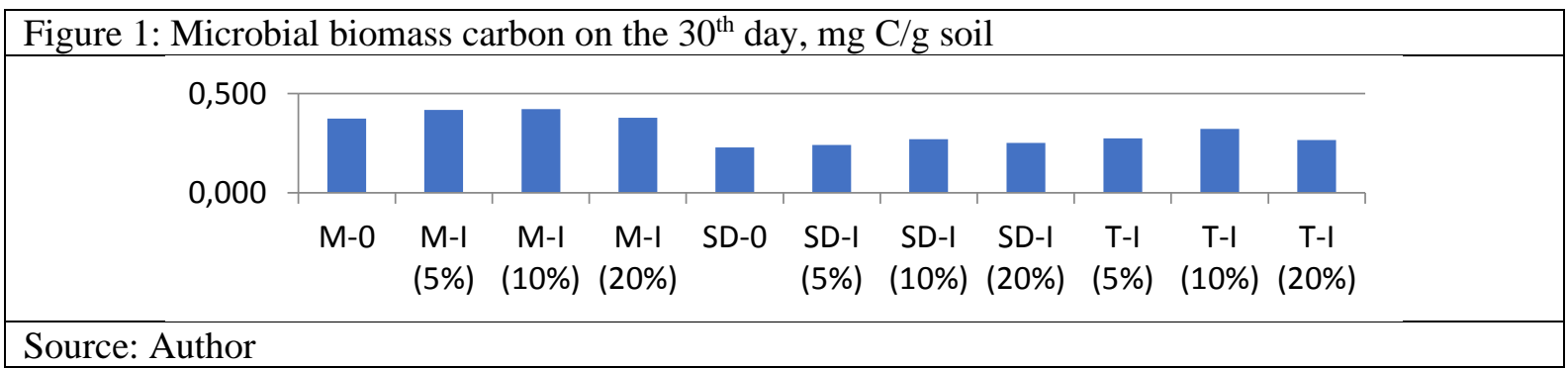

Microbial carbon biomass on the 30th day of the vegetation experiment was higher in variants with the addition of vermiculite compared to controls. In the mine substrate samples, the microbial organic carbon values were highest and up to 1.13 times against control (M-0), decreasing with the addition of $20 \%$ vermiculite. For the variants with vermiculite from soil depot, biomass $\mathrm{C}$ values increased to 1.2fold relative to the control (SD-0), being highest when $10 \%$ vermiculite was added. A similar tendency is observed in the variants with tailings substrates - the highest values of MBC are found in the variant with the addition of $10 \%$ vermiculite - 1.4 times above SD-0. Biomass carbon on the 95th day of reporting follows its distribution trend on the 30th day, increasing by about 1.3-fold (Fig. 2). 


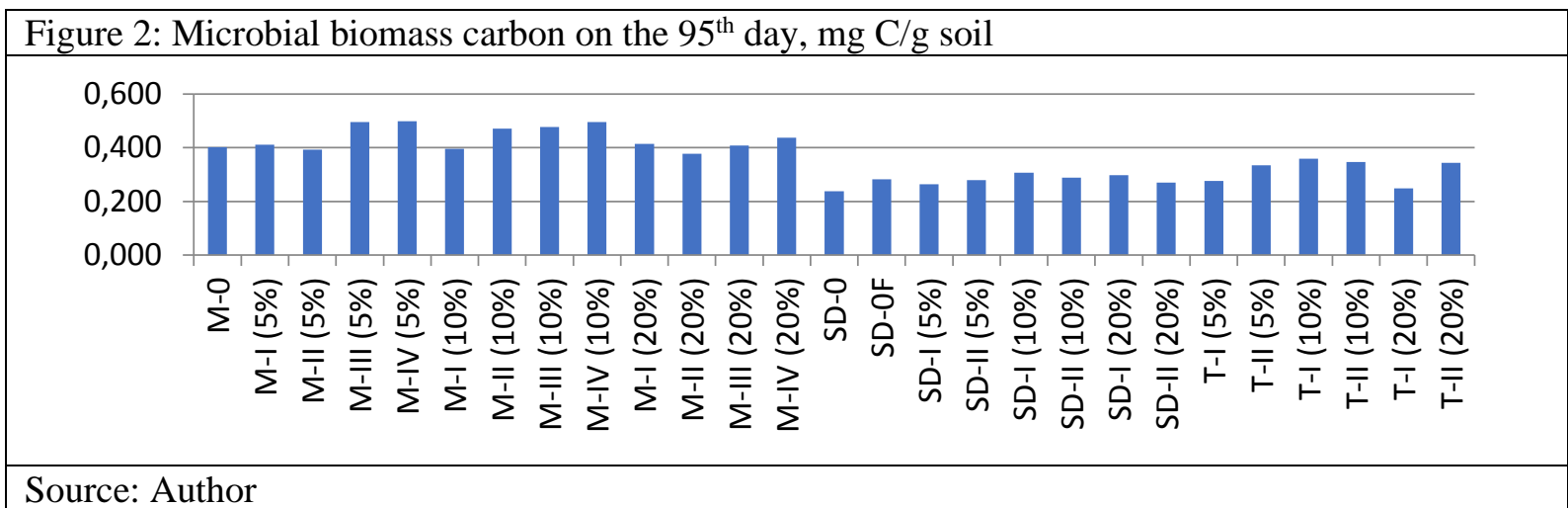

Microbial carbon biomass on the 95th day of the vegetation experiment was higher in the variants where activities were conducted compared to the control samples, such as $\mathrm{S}-\mathrm{OF}>\mathrm{S}-0$. The combined application of lime and fertilizer maximizes microbial biomass. Self-lime application gives better results on this indicator than fertilization alone. The highest MBC values are again established in substrates from the mine. In general, fertilization has a more favorable effect on microbial biomass in tailings samples, with higher values being obtained than in soil depot variants. Overall, the addition of $10 \%$ vermiculite maintains the best results for MBC accumulation.

Cellulase activity is highest in the mine variants (up to 1 time with the addition of 5\% vermiculite and with similar values in the other two samples relative to the control), followed by variants with substrate from the soil depot (up to 1 time relative to the control) and the lowest for tail variants (lower than controls) (Fig. 3).

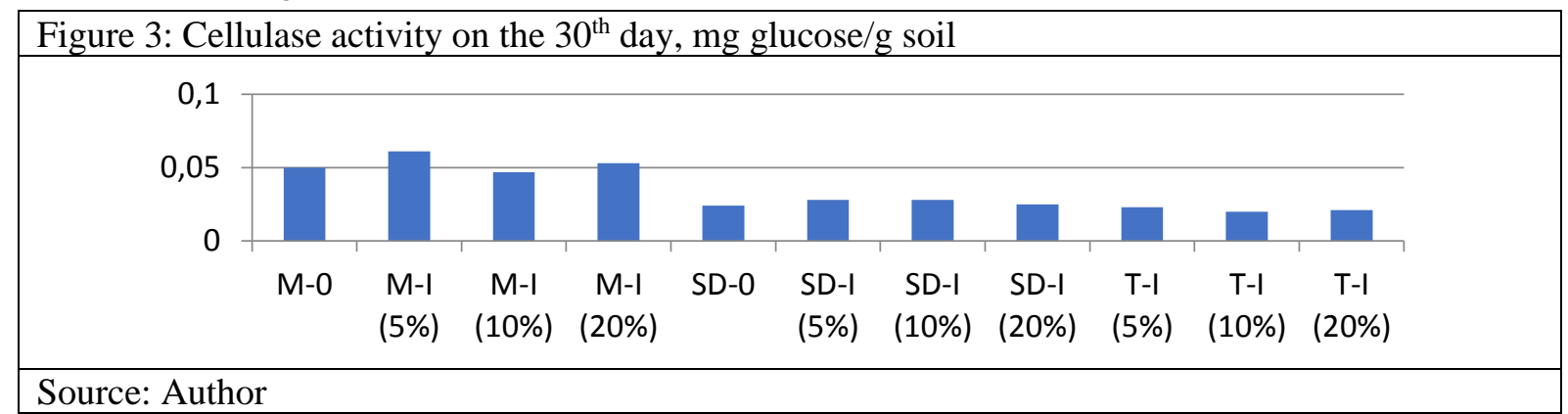

On the 30th day after starting the experiment (before liming and fertilizing), a decrease in cellulase activity was observed with increasing vermiculite concentration. While on the 95th day of starting the experiment (after liming, fertilizing and mowing), this trend reverses - cellulase enzyme activity increases with increasing vermiculite concentration - up to 1.4 times with the addition of $20 \%$ vermiculite, fertilization and liming compared to the control. The highest values of cellulase activity for the variants from mine are found in conducted liming and fertilization, with concentrations growing with increasing amount of vermiculite. Variants "with fertilizing, without liming" show better results than "with liming, without fertilizing". Fertilization increases the activity of cellulase in the other variants also - with substrates from the soil depot and tailing pond, the dependence being again proportional to the increase in the concentration of vermiculite. Higher values of cellulase activity are found compared to day 30 (up to 1.85 times for mine variants, 1.64 times for soil depot variants and 1.85 times for tail variants), which may to be explained, on the one hand, by the fertilization and liming carried out, as well as by an increase in the amount of organic matter in the samples of dying plant residues over time and, accordingly, stimulating the development and activity of the soil microorganisms (Fig. 4).

In general, on the 30th day of the experiment (before liming and fertilizing), a decrease in amylase activity was observed with an increase in the amount of vermiculite. It is highest for the vermiculite mine variants (up to 1.4 times against control), followed by the soil depot variants (up to 1.1 times against control soil) with the lowest enzyme activity seen in the tail variants (up to 1.1 times against controls) (Fig. 5). 
The opposite trend was observed in the results of day 95 - a promotion in amylase activity with an increase in the amount of vermiculite. The combined application of fertilization and liming in variants from the mine increases activity of this enzyme to a greater extent - 1.7 times for variant M-IV (20\%) compared to the control. Variants "with fertilizing, without liming" show in better results than "with liming, without fertilizing". Similar to the break down of cellulose, the degradation of starch in the variants increases after fertilization and liming (Fig. 6).
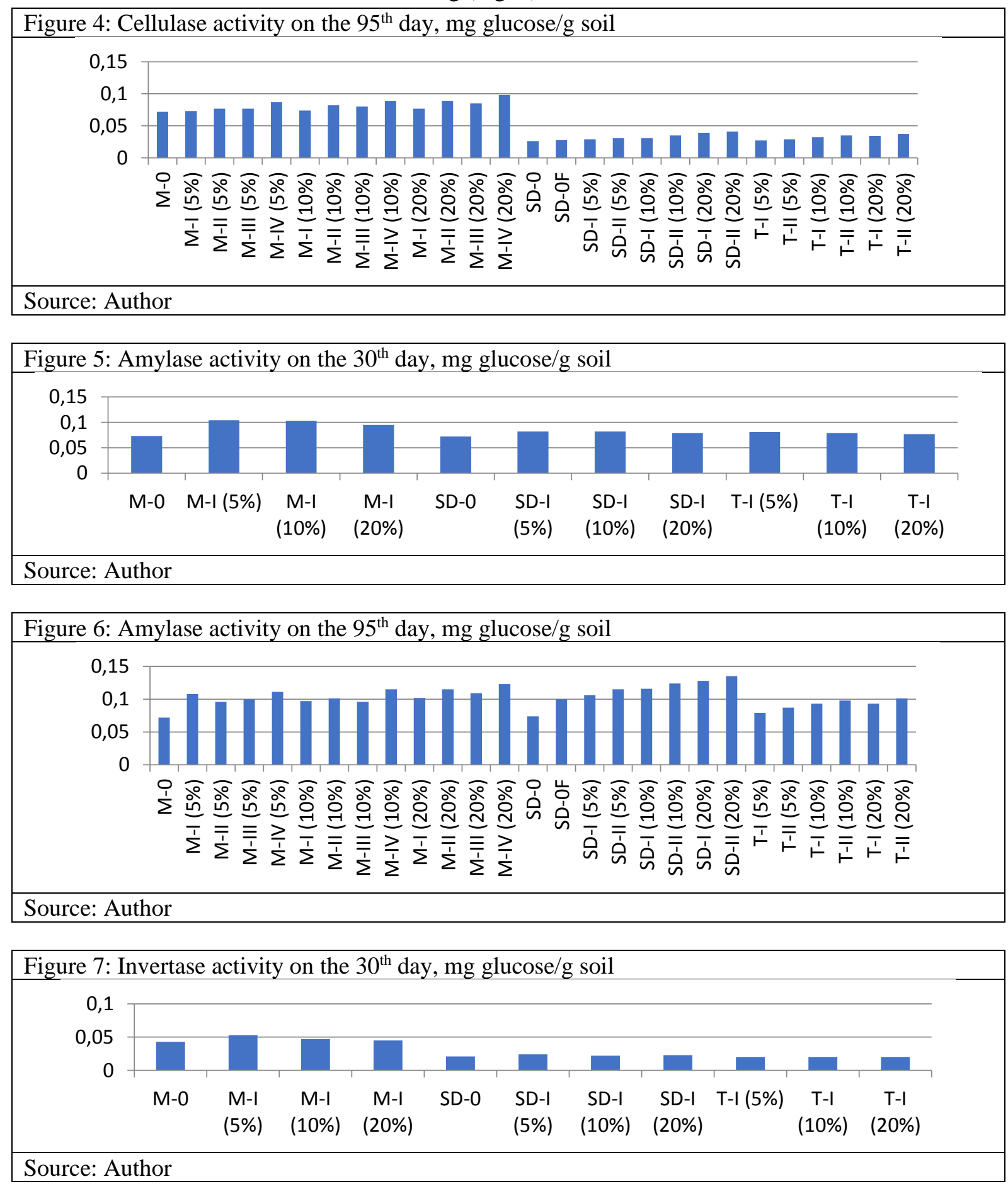

Invertase activity is highest in the mine variants (up to 1.2 times the control), followed by the soil depot (up to 1.1 times the control) and lowest (even lower than the control samples) is the enzyme activity in the tail variants. On the 30th day after starting the experiment a decrease in the activity of invertase enzyme was observed with an increase in the amount of vermiculite. This tendency is clearer for variants of the mine, while for the variants of soil depot the values are close, and for variants with tail the same regardless of the vermiculite concentrations (Fig. 7). 
On the 95th day from starting the experiment (after liming, fertilizing and mowing), invertase activity increased with increasing amount of vermiculite in all variants as well as on the 30th day (Fig. 8).

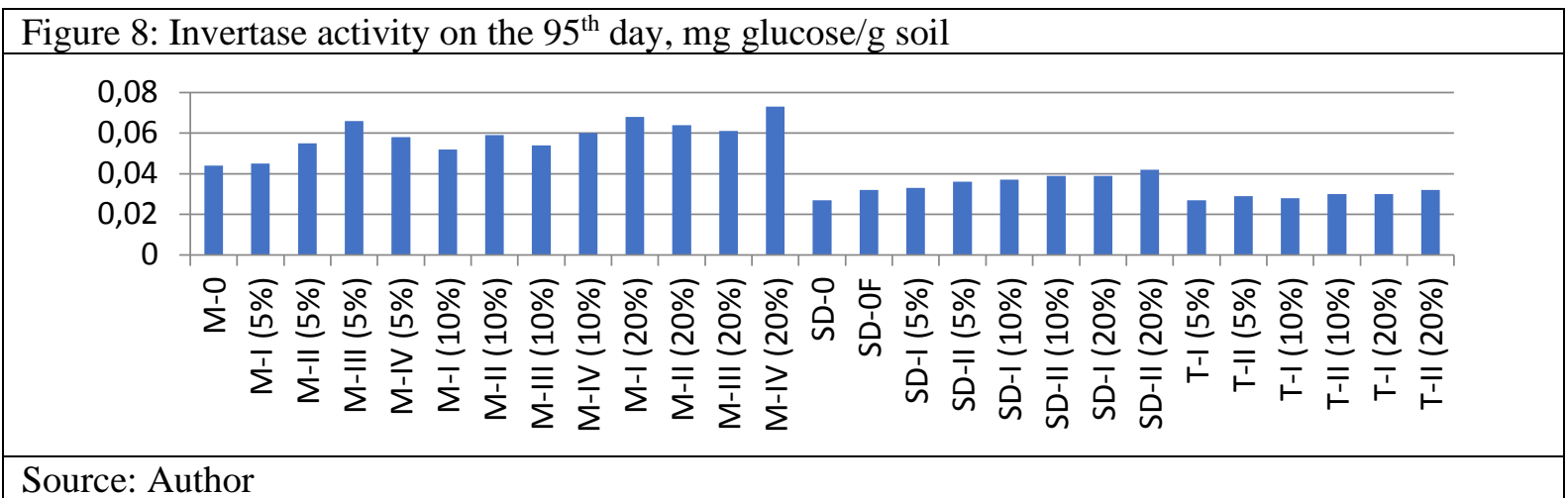

The combined application of fertilization and liming in variants from the mine increases the activity of enzyme to a greater extent - up to 1.7 times in variant M-IV (20\%). Variants "with fertilizing, without liming" show better results than "with liming, without fertilizing". Fertilization and the addition of vermiculite increase invertase activity by up to 1.3 times in soil depot variants, while in tail variants the values of invertase are below control, but in fertilizer variants the results are better than in those without fertilization. In general, activities of the three enzymes follows in descending order: amylase> cellulase> invertase. This trend depends on the type of vegetation and development of certain groups of microorganisms capable of producing the enzymes studied.

Cellulase, amylase and invertase activity break down cellulose, starch and sucrose to glucose, respectively. Degradation of soil glucose to hydrogen peroxide and water is catalyzed by $\beta$ glucosidase enzyme. The toxic hydrogen peroxide is degraded to water and oxygen by the catalase enzyme (final stage of carbohydrate degradation in the soil) (Fig. 9 and Fig. 10).

\begin{tabular}{|l|lllllllll|}
\hline Figure 9: Catalase activity on the $30^{\text {th }}$ day, $\mathrm{ml} \mathrm{O}_{2} / 30 \mathrm{~min}$ & & & & & \\
\hline
\end{tabular}

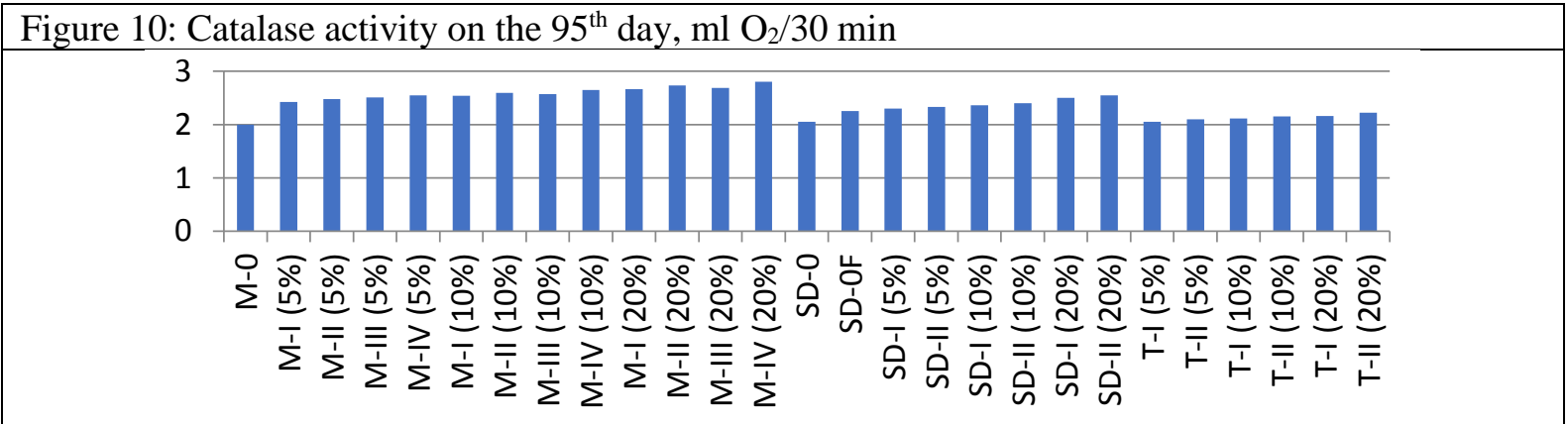

Source: Author

Just like the 30th day, and the 95th day from the start of the experiment, the catalase activity was highest in the variants from the mine, followed by the variants from the soil depot and tailings pond. Activity of this enzyme increases with increasing amount of vermiculite and is highest with the addition of $20 \%$ vermiculite in both study periods - up to 1.3 (30th day) - 1.4 (95th day) times compared to the control sample M-0. Catalase activity in the tailings variants has values above the control ones, i. catalase activity is less inhibited than amylase, cellulase and invertase activity. The highest values of catalase enzyme are after liming and fertilizing. Variants "with fertilizing, without liming" show better results than "with liming, without fertilizing". The lowest and closest to the 
control samples are the values of catalase without liming and fertilizing. Fertilization raises catalase activity as values increase with increasing amount of vermiculite in the samples.

As noted, the accumulation of microbial biomass $\mathrm{C}$ and enzyme activities have the highest values in the most highly contaminated with toxic elements variants - those of the mine. In recent years vermiculite has been widely used for the adsorption of heavy metals (Malandrino et al., 2011; Sis and Uysal, 2014; De Freitas et al., 2017). Furthermore, vermiculite significantly improves the drainage properties of substrates, increases porosity and looseness, prevents sealing and soil compaction, and protects roots from sharp temperature fluctuations.

\section{Conclusion}

Microbial biomass has the highest values in the mine variants, followed by the variants with tail and lowest values has MBC in the variants of soil depot. MBC had higher values after the addition of vermiculite compared to controls, with best results in all variants being obtained at $10 \%$ vermiculitis. The combined application of liming and fertilizing in the mine variants, as well as fertilization in the variants from the soil depot and tailing, increases MBC and enzyme activities to a greater extent.

The activity of all enzymes tested is highest for the mine variants, followed soil depot variants and lowest for the tail variants. On the 30th day from starting the experiment (before liming and fertilizing), a decrease in activity of cellulase, amylase and invertase was observed with increasing vermiculite concentration. Probably irrespective of the accumulated MBC, initially the activity of the microorganisms (respectively the enzyme activity) is suppressed. This conclusion is not borne out by the results of day 95 - where a raising in the enzyme activities with an increase in the amount of vermiculite is seen. While catalase activity increased with increasing amount of vermiculite, it was highest with the addition of $20 \%$ vermiculite in both study periods. Variants "with fertilizing, without liming" show better results than "with liming, without fertilizing".

\section{Acknowledgements}

The variants for this study were developed on the project No. 937/2019.

\section{References}

Baldrian, P., Trögl, J., Frouz, J., Šnajdr, J. et al. (2008). Enzyme activities and microbial biomass in topsoil layer during spontaneous succession in spoil heaps after brown coal mining. Soil Biology and Biochemistry 40(9), 2107-2115. https://doi.org/10.1016/j.soilbio.2008.02.019

Bi, Y.L., Wu, W.Y., Liu, Y.P. (2007). Application of arbuscular mycorrhizas in land reclamation of coal spoil heaps. Acta Ecol Sin; 27(9), 3738-43.

Burns, R.G., De Forest, J.L., Marxsen, J., Sinsabaugh, R.L., Stromberger, M.E., Wallenstein, M.D., et al. (2013). Soil enzymes in a changing environment: Current knowledge and future directions. Soil Biol Biochem 58, 216-234. https://doi.org/10.1016/j.soilbio.2012.11.009

Cai, Y., Peng, Ch., Qiu, S., Li, Y. (2011). Dichromate Digestion-Spectrophotometric Procedure for Determination of Soil Microbial Biomass Carbon in Association with Fumigation-Extraction. Communications in Soil Science and Plant Analysis 42(22), 2824-2834. https://doi.org/10.1080/00103624.2011.623027

Cele, E.N. \& Maboeta, M. (2016). Response of soil enzyme activities to synergistic effects of biosolids and plants in iron ore mine soils. Int. J. Environ. Sci. Technol., 13, 2117-2126. https://doi.org/10.1007/s13762-016-1043-y

Chen, Z., Yang, G., Sun, Q. (2009). Effects of bio-crust on soil microbial biomass and enzyme activities in copper mine tailings. PubMed, 20(9), 2193-8.

Chodak, M., Niklińska, M. (2012). Development of Microbial Biomass and Enzyme Activities in Mine Soils. Pol. J. Environ. Stud., 21(3), 569-577.

De Freitas, E.D., De Almeida, H.J., Vieira, M.G.A. (2017). Binary adsorption of zinc and copper on expanded vermiculite using a fixed bed column. Appl. Clay Sci., 146, 503-509. https://doi.org/10.1016/j.clay.2017.07.004

Dimitriu, P.A., Prescott, C.E., Quideau, S.A., Grayston, S.J. (2010). Impact of reclamation of surface-mined boreal forest soils on microbial community composition and function. Soil Biol Biochem 42, 2289-2297.

https://doi.org/10.1016/j.soilbio.2010.09.001

Doni, S., Macci, C., Masciandaro, G. \& Ceccanti, B. (2012). IEF technique to study the $\beta$-glucosidase-humic complexes in organic and mineral amended soils. In: Soil enzymology in the recycling of organic wastes and environmental restoration (Eds Trasar-Cepeda, C., Hernandez, T., Garcia, C., Rad, C., Gonzalez-Carcedo, S.). Springer-Verlag, Dordrecht, London, New York. https://doi.org/10.1007/978-3-642-21162-1_3

Gil-Sotres, F., Trasar-Cepeda, C., Leirys, M.C., Seoane, S. (2005). Different approaches to evaluating soil quality using biochemical properties. Soil Biol. Biochem. 37, 877. https://doi.org/10.1016/j.soilbio.2004.10.003

Gradova, N., Babusenko, E., Gornova, I. (2004). Laboratornyy praktikum po obshchey mikrobiologii [Laboratory Workshop on General Microbiology], publisher: „DeLi Print”, Moscow, 144p. 
Harris, J.A. (2003). Measurements of the soil microbial community for estimating the success of restoration. Eur. J. Soil Sci. 54, 801. https://doi.org/10.1046/j.1351-0754.2003.0559.x

Khaziev, F. 1976. Fermentativnaya aktivnost' pochv [Enzymatic activity of soils], publisher: „Nauka”, Moscow, 180 p.

Kuimei, Q., Wang, L., Ningning, Y. (2012). Effects of AMF on soil enzyme activity and carbon sequestration capacity in reclaimed mine soil. International Journal of Mining Science and Technology 22, 553-557. https://doi.org/10.1016/j.ijmst.2012.01.019

Kwak, J., Chang, S., Naeth, M., Schaaf, W. (2015). Coarse Woody Debris Increases Microbial Community Functional Diversity but not Enzyme Activities in Reclaimed Oil Sands Soils. PLoS One, 10(11): e0143857. https://doi.org/10.1371/journal.pone.0143857

Ladd, J.N., Amato, M., Grace, P.R., van Veen, J.A. (1995). Simulation of C-14 turnover through the microbial biomass in soils incubated with C-14-labeled plant residues. Soil Biol Biochem 27, 777-783. https://doi.org/10.1016/00380717(94)00243-T

Malandrino, M., Abollino, O., Buoso, S., Giacomino, A., Gioia, C., Mentasti, E. (2011). Accumulation of heavy metals from contaminated soil to plants and evaluation of soil remediation by vermiculite. Chemosphere 82, 169-178. https://doi.org/10.1016/j.chemosphere.2010.10.028

Petrova, R. (2009). Resheniya za rekultivatsiya i fitoremediatsiya na degradirani pochvi - medno khvostokhranilishte „Medet” [Decisions for rehabilitation and phytoremediation of degraded soils - copper tailling pond 'Medet']. Forestry ideas 2(38): 68-77.

Petrov, P. (2019). Podkhodi pri rekultivatsiyata na Iztochno nasipishte, Rudnik „Elatsite“ [Approaches to the reclamation of Eastern embankment, Ellatzite Mine], publisher: „Avangard prima”, 155p. ISBN 978-619-239-295-6.

Qiang, L., Qingjing, H., Chaolan, Zh., Zhenjiang, J. (2018). Effects of Pb, Cd, Zn, and Cu on Soil Enzyme Activity and Soil Properties Related to Agricultural Land-Use Practices in Karst Area Contaminated by Pb-Zn Tailings. Pol. J. Environ. Stud., 27(6), 2623-2632. https://doi.org/10.15244/pjoes/81213

Stefanova, V., Petrov, P. (2019). Soil development and properties of microbial biomass succession in reclaimed sites in bulgaria. International conference on innovations in science and education march 20-22, 2019, Prague, Czech republic, 1-9. https://doi.org/10.12955/cbup.v7.1492

Stefanova, V., Petrov, P., Zheleva, E. 2019. Assessment of the soil formation process in reclaimed terrains in Bulgarian copper mine. ICIR EUROINVENT 2019 IOP Conf. Series: Materials Science and Engineering. https://doi:10.1088/1757 $899 \mathrm{X} / 572 / 1 / 012107$

Sis, H., Uysal, T. (2014). Removal of heavy metal ions from aqueous medium using Kuluncak (Malatya) vermiculites and effect of precipitation on removal. Appl. Clay Sci., 1-8. https://doi.org/10.1016/j.clay.2014.03.018

Veen, J.A. \& Kuikman, P.J. (1990). Soil structural aspects of decomposition of organic-matter by microorganisms. Biogeochemistry 11: 213-233. https://doi.org/10.1007/BF00004497

Wang, L.P., Qian, K.M., He, S.L., Feng, B. (2009). Fertilizing effect of arbuscular mycorrhizal fungi on coal mine complex substrate. Procedia Earth Planet Sci, 1(1):1101-6. https://doi.org/10.1016/j.proeps.2009.09.169

Wang, Y., Li, Y., Wang, H., Guo, J. et al. (2008). Effects of vegetation restoration pattern on microbial quantity and enzyme activity in iron tailings. CJE, 27(10), 1826-1829. 